\title{
UNOFFICIAL SELVES
}


By the same author

GEORGE ELIOT: MIDDLEMARGH: A CASEBOOK (editor) AN INTRODUCTION TO SHAKESPEARE'S COMEDIES 


\section{UNOFFICIAL SELVES}

Character in the Novel from Dickens to the Present Day

PATRIGK SWINDEN

Macmillan Education 


\section{(C) Patrick Swinden 1973}

Softcover reprint of the hardcover 1st edition 1973 All rights reserved. No part of this publication may be reproduced or transmitted, in any form or by any means, without permission.

First published 1973 by

THE MACMILLAN PRESS LTD

London and Basingstoke

Associated companies in New York Dublin

Melbourne fohannesburg and Madras

SBN $333 \quad 144422$

ISBN 978-1-349-01762-1 ISBN 978-1-349-01760-7 (eBook)

DOI 10.1007/978-1-349-01760-7 
for

Frank Anderson 


\section{Contents}

Acknowledgements ix

I Nothing bUt the TRUTh I

Some modern theories of fiction. Kermode. Josipovici.

2 Deaths and Entrances

Dickens. Other Victorians.

3 Detachment 62

European realism. Flaubert. Robbe-Grillet and the nouveau roman. Turgenev and Tolstoy.

4 Registration

Henry James.

5 Time and Motion

I 20

English realism. Ford. Bennett. V. S. Naipaul.

6 Growing Pains

Romanticism and the novel. D. H. Lawrence.

Richard Hughes.

7 Plots

The Concept of Nature. Bayley. Iris Murdoch.

Dan Jacobson. Muriel Spark.

Bibliography

Index 


\section{Acknowledgements}

The genesis of this book lies in the work I completed as a research student at Cambridge. The subject was the English and European influences on the novels of Ford Madox Ford. By the time I had submitted my dissertation, I was dissatisfied with my account of the theory of realism which lay at the centre of the argument. I was also dissatisfied with realist theory itself. Some of the grounds for my dissatisfaction became clearer to me in conversation with Malcolm Bradbury and Tony Tanner, to whom I am grateful for making me re-think the issues involved. I am also grateful to my supervisors at Cambridge, John Beer and Alison Fairlie. My debt to John Bayley, whose books on narrative fiction I have read with great pleasure, will be obvious.

I have benefited from the advice and encouragement of several people during the preparation and actual writing of this book. To my colleagues at Manchester I owe a debt, especially to Professor C. B. Cox and Mrs Felicity Currie. Most of all I am indebted to my wife, Serena, for her continuing contribution to the ideas expressed here, and to the teacher to whom this book is dedicated.

Finally I should like to thank Mrs Nancy Walsh for her labours, both typographical and diplomatic, in the preparation of the book for publication.

P. S.

The author and publishers wish to thank the following, who have kindly given permission for the use of copyright material: Mrs Dorothy Cheston Bennet, Hodder \& Stoughton Ltd, and Doubleday for the extract from The Old Wives' Tale by Arnold Bennett; Calder and Boyars Ltd and Grove Press Inc. for extracts from La falousie from Two Novels, copyright (C) 1959 by Grove Press Inc., and Pour un nouveau roman from For $A$ New Novel: 
Essays on Fiction, copyright (C) I 965 by Grove Press Inc., both by Alain Robbe-Grillet; Chatto \& Windus Ltd and Harper \& Row, Publishers, Inc., for extracts from In Hazard and The Fox in the Attic by Richard Hughes; André Deutsch Ltd and Curtis Brown Ltd for the extract from A House For Mr. Biswas by V. S. Naipaul; Editions du Seuil and Farrar, Straus \& Giroux Inc., for the extract from Le dégré Zéro de l'écriture by Roland Barthes; The Hogarth Press Ltd, the author's Literary Estate and Harcourt Brace Jovanovich Inc., for the extract from The Common Reader by Virginia Woolf, copyright 1925 by Harcourt Brace Jovanovich Inc., copyright 1953 by Leonard Woolf; Laurence Pollinger Ltd and the Estate of the late Mrs Frieda Lawrence and The Viking Press Inc., for the extracts from Sons and Lovers by D. H. Lawrence and The Collected Letters of D. H. Lawrence. 
'Official sentiments are one thing

We are extra-official.'

Wemmick to Pip in Great Expectations 